Business Advice by Accountants to SMEs: Relationships and Trust

\begin{tabular}{|r|l|}
\hline Journal: & Qualitative Research in Accounting and Management \\
\hline Manuscript ID & QRAM-04-2017-0022.R2 \\
\hline Manuscript Type: & Original Article \\
\hline Keywords: & external accountant, business advice, relationships, trust, SME \\
\hline \multicolumn{2}{|l}{} \\
\hline
\end{tabular}

SCHOLARONE $^{\text {IM }}$

Manuscripts 


\section{Business Advice by Accountants to SMEs: Relationships and Trust}

\section{Introduction}

There is a growing body of literature that focuses on the external relations of SMEs as a means of resource acquisition for decision making (Dyer and Ross 2007; Blair and Marcum 2015; Carey and Tanewski 2016). External accountants are used extensively and they are reported to be the most frequently sourced professional advisor in the small and medium sized enterprise $(\mathrm{SME})^{1}$ environment (Kirby et al. 1998; Bennett and Robson 1999; Gooderham et al. 2004; Carey et al 2005; Blackburn and Jarvis 2010; Stone 2011, 2015). The literature details variation in the level and type of accounting advisory services sourced by SMEs (e.g., Carey and Tanewski 2016; Blackburn and Jarvis 2010), yet it provides only limited theoretical insight explaining variation on the extent to which external accountants are used as business advisors (Bennett and Robson 1999; Gooderham et al. 2004). ${ }^{2}$ While agency theory has some application, it provides an incomplete explanation as to why SMEs may or may not choose to buy business advice from their external accountants. This study contributes to the literature by developing a conceptual framework that focuses on the influence of relationships and trust in explaining the SME's decision to purchase business advice from their external accountants. Within the context of this conceptual framework, the study also uncovers significant new leads and insights into the behaviour of SME owner-managers when it comes to purchasing business advice.

Understanding the role that relationships and trust play in enabling the purchase of business advice is important to the accounting profession. The American Institute of Certified Practising Accountants (AICPA) predicts that the future of accounting will no longer be defined by traditional services. Given this transformation in the accounting profession and calls from the AICPA directing the accountant to become a more rounded "trusted business advisor" (Hartstein 2013), this paper is significant and timely as it develops a conceptual model that will assist the

\footnotetext{
${ }^{1}$ There are varying definitions of SME. In the U.S., a small business encompasses all independent enterprises with fewer than 500 employees (U.S. Census Bureau 2009; U.S. Small Business Administration 2014). However, in the U.K., a SME is a business that employs less than 250 people and includes the following categories: a micro-business $<10$ people, a small business 10-49 people, and a medium-sized business 50-249 people (see Department for Business Innovation and Skills 2009). In Australia, (see the Australian Bureau of Statistics 2001), a micro-business is $<5$ employees, a small business is 5-19 employees and a medium-sized business is 20-200 employees.

${ }^{2}$ We define business advice broadly as ancillary professional services provided by accountants to assist or advise clients in their strategic direction and operational running of their firms. These professional services are usually offered in addition to "traditional" accounting services such as compilation, taxation and auditing services.
} 
profession in better understanding the complex dynamics of the accountant-client relationship in the provision of business advice.

Our conceptual model distinguishes, for the first time, the antecedent factors of demand for business advice from the enabling roles of relationships and trust. Antecedent in this case refers to the existing conditions of the enterprise (e.g., firm size, institutional debt, firm age, and growth rate or intention to grow). Enabling conditions relate to the trust (ability, integrity, empathy and propensity to trust) emanating from the existing relationship (social rapport, understanding of business needs) that may activate latent demand. Whilst the literature has identified a range of factors associated with the SME's decision to purchase business advice, Blackburn and Jarvis (2010) argue that the influence of these factors is ambiguous. Given this lack of clarity, a primary contribution of our paper is to organise these factors into a conceptual model which distinguishes antecedent demand factors from enabling (mediating) factors (relationships and trust) that are associated with demand for business advice by SMEs. An antecedent demand factor is one that causes an SME to seek advice; such as how to grow the business (i.e., intention to grow, see Gooderham et al. 2004). However, rather than postulating that relationships and trust are antecedents of demand for business advice, our conceptual framework contributes to understanding by suggesting that relationships and trust are preconditions enabling latent demand for business advice by SMEs to be realised. An SME might demand advice, but will only purchase the advice when they trust their accountant and the relationship between the SME and their accountant can contribute to nurturing the trust required for an SME to purchase business advice.

We verify the conceptual model by interviewing 20 SME owners and accountants to gain insights into transactional exchanges between SME clients and their accountants. Interview data support the conceptual framework's proposition that relationships and trust are necessary conditions for enabling latent demand for business advice. Although demand factors such as size, debt, age, growth and intention to grow will determine an SME's ex ante need for advice, the enabling factors of relationships and trust are influential in whether business advice is actually taken up. Our field research also uncovered significant new insights from participants into how specific personality traits of SME owner-managers relating to trust can influence decisions to purchase external business advice. This in turn has provided a deeper and more nuanced understanding of the role of personal trust in the accountant-client relationship, particularly as it 
relates to decisions to purchase business advice. Our fieldwork also uncovered three additional antecedent demand factors not identified in the extant literature - economic conditions, environmental turbulence and business life-cycle - that influence the decision to purchase business advice.

Our results further contribute to the literature by questioning the commonly held belief that the relationship an accountant establishes with an existing SME client, via compliance work, will lead to the provision and take-up of non-compliance advice and support (Blackburn and Jarvis 2010; Gooderham et al., 2004). The application of our conceptual framework in the fieldwork enabled us to unpack this assumption that an already established relationship, developed while providing compliance services, will automatically lead an SME to buy business advice. A more complex range of factors need to be satisfied before a SME purchases business advice.

While the fieldwork revealed that all external accountants perceived themselves as having the necessary competence to provide useful business advice, SME owner-managers expressed mixed views on this issue. This is consistent with a number of prior studies which suggest that external accountants do not always have the business expertise necessary to add value as business advisers (Marriott et al. 2008; Burke and Jarratt 2004; Deakins et al. 2001). Ostensibly, external accountants may be well placed to offer business advisory services to their SME clients on the back of compliance services, and indeed are better placed than most other providers (Mole 2002), but they need to convince clients that they have the necessary business expertise beyond their compliance capabilities. In particular, the fieldwork reveals the critical importance of industry-based knowledge to establishing the competence of accountants as business advisers. Findings thus highlight that an expectation gap exists between SME owners' perceptions and external accountants' ability to provide advice.

The remainder of the paper is organised as follows. The next section provides a context for our study, an overview of the literature and an explanation of the conceptual framework. This is followed by an explanation of the qualitative research design used to corroborate the conceptual framework, an exposition of the results, and the paper's conclusions, implications and recommendations. 


\section{Context and Unpacking Relationships in Business Advisory Services}

The AICPA has predicted that the future of accounting services will be so varied and diverse that the concept of core "traditional" services will no longer be representative of the profession (AICPA 2011, p.44). This has led to calls by the AICPA to change the dynamic of the accountant-client relationship by highlighting the accountant's more rounded 'trusted business advisor" status (Ferguson 2012; Hartstein 2013; ICPAS-CPA Australia Roundtable 2013). Practically, whether or not accountants desire, or are able, to realise this vision remains to be seen. Nevertheless, the AICPA's prediction reflects a notable trend in the accounting profession over the past decade, namely, that the 'bread and butter' compliance services of many accountancy practices such as taxation, compilation and audit are diminishing due to extensive use of computer technology by SMEs for doing their own accounts and to the introduction of audit exemptions in some jurisdictions such as the UK (Doving and Gooderham 2008; Blackburn and Jarvis 2010; Professional Oversight Board 2010; Kitching et al. 2011; Jarvis and Rigby 2012).

As a result, small and medium sized accounting practices (SMPs) have been seeking to widen their portfolio of services by expanding their ancillary services to include 'business advice' alongside traditional statutory/compliance-type services (Parker 2001; Anderson-Gough et al. 2002; Greenwood et al. 2002; Gooderham et al. 2004; Berry and Sweeting 2006; Fogarty et al. 2006). These developments mimic trends among the larger accounting practices, for which business advisory services have for some time been an important source of revenue growth to offset a stagnating market in audit and tax services (Anderson-Gough et al. 2002; The Economist 2010; Professional Accountancy Association 2010). Despite this transformation in the accounting profession and calls from the AICPA directing the accountant to become a more rounded "trusted business advisor" (Hartstein 2013), there is a lack of clarity in the literature as to why SMEs purchase business advice from their external accountant.

Research investigating determinants of SME demand for business advice has identified firm size, age, institutional debt, growth rate and intention to grow as factors that drive demand for business advice by SMEs (e.g. Holmes and Nicholls 1989; Kirby et al. 1998; Bennett and Robson 1999; Gooderham et al. 2004; Carey et al. 2005; Berry and Sweeting 2006). The literature also suggests that a number of barriers exist to firms taking up business advice, 
${ }^{3}$ The relationship marketing literature also suggests that characteristics of the business adviser that are 'offerrelated' (i.e. competence, reliability, promptness) and 'person-related' (i.e. empathy, politeness) can affect the relationship as well as the establishment of trust (Grönroos 1990). Accordingly, Gounaris and Venetis (2002) suggest that different dimensions of trust will evolve during the development of a client-supplier relationship and that understanding such relationships is a key to understanding trust. Ongoing business relationships are based on information exchanges that over time lead to trust, which in turn is likely to affect both the quality of the information exchanged and of the relationship developed (Denize and Young 2007). In other words, business relationships may lead to the development of trust between parties over time, by minimising potential uncertainties and facilitating a better understanding of mutual needs and competencies. 
accountant to determine the client's needs. As a consequence of their intangible nature, business advisory services exhibit credence attributes and are prone to ex ante information problems. The relationship established while providing compliance type services might allow an accountant to overcome information asymmetries associated with business advisory services. We now turn to a discussion of trust in the extant literature.

\section{Conceptualising Trust}

The use of the term 'trust' is widespread in the literature examining inter-firm relations. Trust, it is argued, reduces transaction costs (Andaleeb 1992), is a source of competitive advantage (Barney and Hansen 1994), limits uncertainty and opportunism (Achrol 1997), and decreases business risks in hostile or turbulent environments (Puffer, McCarthy and Boisot 2010). Trust is also essential for understanding any business relationship because “... to understand how any [business] relationship works, one must ... address the boundaries of trust within that relationship" (Tomkins 2001, p. 165). The role of trust within organisations has been explored in organisational literature (e.g. Kramer and Tyler 1996; Nooteboom 2002) and in management accounting literature (e.g. Busco et al. 2006). Trust also has been examined in an interorganisational context (e.g. Tomkins 2001), in the entrepreneurship literature (Welter, 2011), as well as in specific institutional environments (e.g., Puffer et al. 2010; Welter 2011).

Evidence shows that small business owner-managers choose advisors based on 'previous use', personal 'recommendation' and advisors' understanding of their clients' business context (e.g. Bennett and Smith 2004; Edwards et al. 2010; Blair and Marcum 2015). Bennett and Robson (1999) attribute the position of accountants as the leading advisors to SMEs to their status as 'high trust' providers who work within government-backed, self-regulatory frameworks of training, qualification and codes of conduct, all of which reinforce institutional trust (see also Cowton 2009). While trusted sources might provide a means of helping firms to overcome information asymmetries, the role of trust in the SME-accountant relationship and in the dynamics of that relationship lacks conceptual depth.

In defining trust in the context of this present research, a number of dimensions are relevant. Perceived trustworthiness encompasses both cognitive and affective (or emotional) beliefs that one party will not exploit another's vulnerability (Anderson and Weitz 1989; Tyler and Stanley 2007). Indeed, Möllering (2002) argues that perceived trustworthiness is ultimately 
cognised only through ' $\ldots$ the eyes of the beholder' (p. 140). Trusting behaviour involves actions that incline one party towards risk, uncertainty or vulnerability to another whose behaviour is not under their control (Zand 1972; Tyler and Stanley 2007). Trust as a behavioural intention or reliance on a partner refers to a dimension of trust defined by Moorman et al. (1993, p. 82) as the 'willingness to rely on a partner in whom one has confidence'. Trust as socially-defined phenomenon is characteristic of the social fabric that facilitates interactions among parties, thus taking into account interpersonal behaviours, communication channels and interpersonal trust ties (Håkansson 1982; Lewicki, McAllister and Bies 1998; Tyler and Stanley 2007).

While there are many definitions of trust in the literature, our conceptual framework adopts the model of trust developed by Mayer, Davis and Schoorman (1995), which includes factors relating to the trustor (i.e., ability, benevolence and integrity) and the trustee (i.e. the propensity to trust). Trust is a complex issue and the seminal definition by Mayer et al. (1995) is appropriate because it applies to business transactions, such as between accountants and their SME clients, and captures the complex and dynamic elements of trust. This study is contextualised in a business environment (Welter 2011; Welter and Smallbone 2006) and the definition of trust that we adopt recognises that commercial relationships are not governed by personal trust, but are conditional on specific situations (Nooteboom 2002). Mayer et al. (1995) define trust as:

'The willingness of a party to be vulnerable to the actions of another party based on the expectations that the other will perform a particular action important to the trustor, irrespective of the ability to monitor or control that other party' (p. 712).

This definition implies that we can never remove all uncertainty precisely because of information asymmetry between the trustor and trustee.

Mayer et al. (1995) postulate that the three key antecedent characteristics that lead to being trusted are ability (competence), integrity and empathy (benevolence) ${ }^{4}$. Ability (competence) is characterised in the present study as the degree to which SME owner-managers perceive their external accountant to possess the skills and knowledge to provide advice, a factor

\footnotetext{
${ }^{4}$ Two of the antecedent characteristics of trust (competence, integrity) are also core principles in the code of ethics for professional accountants. The core ethical principles are competence, integrity, objectivity, independence and confidentiality (APES 110, 2008).
} 
identified as influential in Gooderham et al. (2004); Integrity is characterised as the extent to which SME owner-managers believe that the external accountant will adhere to a set of principles they find acceptable (i.e., the code of ethics for professional accountants); and empathy (benevolence) is characterised as the extent to which SME owner-managers believe that the external accountants will act in their best interests, by understanding and genuinely caring about their clients' business and personal needs. The final element in the Mayer et al. (1995) model is the trustors' Propensity to trust, which suggests people differ in their inherent propensity to trust and this is something akin to a personality trait that a person would carry from one situation to another. Gooderham et al. (2004) provides some support for this suggestion about trust, arguing that receptiveness to business advice was influential in small Norwegian businesses' decisions to rely on their accountants as business advisors. Propensity to trust is characterised in the present study, as an SME owner-manager's willingness to trust their accountant.

\section{Conceptual Framework Explaining SME Demand for Business Advice}

The literature review has identified a number of demand factors associated with the SMEs' ex ante need for business advice. Although the literature suggests that relationships and trust play a role in the service exchange, the role of relationships and trust in influencing the purchase of business advice by an SME from their external accountant remains unclear. Figure 1 below lists the ex-ante demand factors ( 1 to 5$)$, the relationship factors $(9.1,9.2)$, and the trust factors (10.1 to 10.5), that have been identified in the literature as potentially influencing a SMEs decision to purchase business advice.

\section{Insert Figure 1. Conceptual Framework for Business Advice Derived from the Literature}

Extant research has not fully explained the process behind the role played by relationships and trust in the provision of business advice by accountants to their SME clients. We propose that relationships and trust are necessary conditions that enable or connect SME latent demand for business advice with the external accountant providing such services. In particular, we distinguish the antecedent factors of demand for business advice - such as size, debt, age, growth 
rate and intention to grow (see ex-ante demand factors in Figure 1) - from the enabling roles of relationships and trust which are necessary in facilitating latent demand for business advice by SMEs. An SME might demand advice, but we propose that an SME will only purchase the advice when they trust their accountant and the relationship between the SME and their accountant can contribute to nurturing the trust required for an SME to purchase business advice.

Our conceptual model thus provides an exploratory framework for how the interplay of social rapport and understanding business needs (two elements identified in the relational marketing literature explaining business relationships between suppliers and clients), as well as ability (competence), integrity, empathy (benevolence), and propensity to trust (the antecedent trust factors related to the trustor and trustee identified in Mayer et al. 1995) are the building blocks that assist in forming a quality relationship between the accountant and their client. Figure 2 below depicts how the ex-ante demand factors and the enabling (or mediating) role of relationships and trust influence whether business advice is actually taken up by the SME client (the jagged lines in Figure 2 represent relationships between the ex-ante demand and the enabling factors and between the enabling factors and the dependent variable). These proposed relationships are examined in our data collection and analysis. Demand factors 6, 7 and 8 represent three additional antecedent demand factors not previously identified in the extant literature, which were identified in the fieldwork.

We contribute to the literature by developing a dynamic conceptual model that provides greater clarity to the purchase of credence services such as business advice by distinguishing the antecedent factors (e.g., firm size, institutional debt, firm age, and growth rate or intention to grow) from the enabling roles of relationships (e.g., social rapport, understanding of business needs) and trust (e.g., ability, integrity, empathy and propensity to trust). This model also will assist the profession in better understanding the complexity of the accountant-client relationship in the provision of business advice. Our fieldwork tests the importance of each conceptual item in relation to an SME's decision to purchase business advice as well as the relationship among the various elements of the conceptual model.

\section{Insert Figure 2. Proposed Conceptual Framework for Business Advice}


The remainder of the paper is organised as follows. The next section provides an explanation of the qualitative research method used to corroborate the conceptual framework. This is followed by an exposition of the results and the paper's conclusions, implications and recommendations.

\section{Research Methods}

We used semi-structured interviews to examine our conceptual framework. This approach was considered most appropriate to assist understanding of transactional exchanges between clients and advisors and, more importantly, permitted us to discern the enabling role of relationships and trust in the provision of business advice by external accountants to their SME clients (AndersonGough et al. 2002). Data were collected through face-to-face interviews with eight SME owners and twelve accountants in London, England, and in Melbourne, Australia. Face-to-face interviews with business owners and external accountants allowed us to probe the influence of the elements of our conceptual model (antecedent demand factors and the enabling roles of relationship and trust) on SMEs' decisions to purchase business advice from their external accountants.

We conducted interviews in two cities to ensure external validity of our interview data. Although contracting environments vary across countries, La Porta et al. (2000) identify both Australia and the UK as having shared common Anglo-Saxon traditions, similar regulatory environments, shared compliance with international accounting standards and international codes of professional conduct, and comparable business approaches. We did not expect that focusing on two institutional (contracting) and cultural environments - in London and Melbourne - would have a significant influence on our findings. However, by conducting interviews in these two jurisdictions and among different (heterogeneous) accounting and SME firms, we ensured that our findings would be more robust and externally valid and, thus, more likely to be useful in understanding our conceptual model.

Given the relatively low levels of knowledge about the motivations, characteristics and population of SME firms purchasing business advice from their current external accountants, this study used a purposive sample, following a convention in qualitative research (Kuzel 1992; Chua 1996). In order to identify SME firms and accounting practices of potential interest, the research 
team in Australia used the assistance of a management consultant to gain access to SME firms, while key accounting informants were approached through their professional memberships of CPA Australia and The Institute of Chartered Accountants in Australia (ICAA). In the UK, researchers relied on gaining access to SME owners through networks and contacts that the researchers had established over many years, while accountants were approached through their membership of the ICAEW.

Initially, $38 \mathrm{SME}$ owners and accounting partners were identified and contacted by the research team. Some were excluded from the fieldwork because they were insufficiently qualified, not interested or unable to participate due to scheduling conflicts. This initial screening process yielded a list of 20 active study participants, including 12 external accountants and eight SMEs. Of the accounting practices, six were $2^{\text {nd }}$-tier firms with international affiliation, two were medium-sized firms and two were small firms. Eight SME owner-managers - or partner/shareholders of the organisations - were selected on the dual criteria of having some autonomy over decision-making within the enterprises, and having experience dealing with the firms' external relations.

The interviews followed a protocol of 25 broad guiding questions (see Appendix A), instructed by the key elements in the conceptual model. Prior to use, the interview guide was extensively critiqued by several academics and accountants. The interview guide provided scope for exploration of issues that emerged in the interview and, at the same time, allowed for direct corroboration of our conceptual model. Thus, use of an interview protocol addressed the issue of reliability of the qualitative data, whereas replication and verification of similar patterns and themes across the different interviews ensured the external validity of the qualitative data. The interviews were of 60 to 90 minutes duration and took place in the interviewees' workplaces between July 2008 and March 2009. All the interviews were audio recorded and transcribed.

The 20 participants generated qualitative data that was sufficient to provide reliable variability, to determine the themes related to the components of the conceptual model and to draw conclusions. Our approach in this respect is supported by the findings of Guest et al. (2006), who contended that major themes were usually present after six interviews, that 
qualitative data reached a point of saturation at around 12 interviews, and that subsequent interviews no longer provided thematic insight.

The interviews provided us with deep insights into the perceptions of the ownermanagers and external accountants regarding the influence of the components of the conceptual model. Each interview focused on the business owners' interactions with accountants on firmrelated matters rather than individual, personal matters. However, this distinction between 'business-specific' and 'person-specific' advice becomes increasingly opaque when ownermanagers require advice spanning individual and firm-related issues. This is often the case, for example, in family firms and micro-firms where the income of the firm is indeed that of the individual and there is a blurring of the lines between work and home issues.

The main method of analysis involved theme-building around components of the conceptual model. This was initially achieved via the use of open coding - that is, a qualitative data coding process requiring the researchers to go through each transcript line-by-line, breaking down the data by examining, comparing and contrasting it, followed by categorising the interview transcripts (Miles and Huberman 1994). Indeed, all members of the research team read through all the transcripts to build up a thematic analysis of the influence of the components of the conceptual model on SMEs' decisions to purchase business advice. Open coding was performed because it is an iterative process, allowing for the comparison of similarities and differences among the transcripts, as well as building up an understanding of the influence of the various elements of the conceptual model. More importantly, the iterative process undertaken during the review of the transcripts allowed us to gain insights by better understanding the interactions in the evolution of the relationships between accountants and clients, the conditions under which trust develops, and what factors enable decisions to purchase business advice from accountants. Open-coding was conducted over several weeks, and each manuscript's coding scheme was checked independently by at least two members of the research team.

\section{The Market for Business Advisory Services Bought From External Accountants by SMEs}

Purchases of business advisory services by SMEs from their external accountant are shown in column 4 of Table 1. Results suggest that while some firms relied on their external accountants 
as advisors (SME02, SME05, SME06 and SME07), others purchased a more limited range of advisory services (SME03, SME04), and some purchased no advice (SME01, SME08).

\section{Insert Table 1 here}

The types of business advisory services provided by external accountants to SME clients are shown in column 4 , Table 2 . The advisory services span matters directly relevant to the SME businesses, through to matters that require them to act as trusted confidantes and advisors on private and family matters.

\section{Insert Table 2 here}

A review of the business advisory services bought by SMEs (Table 1) and the services offered by accountants to their SME clients (Table 2) suggest the following categories:

- Financial services: cash flow and banking, and advice on individual and family issues: superannuation (retirement planning), asset structuring, income distribution, and wealth accumulation strategies.

- Business operational services: production efficiency, lease negotiation, payroll, HR or information technology (IT).

- Business dynamics: on the purchase, transfer or sale of a business.

- Intangible services: being a 'sounding board', psychologist and friend.

- Family services: wills, estate planning, succession planning and mentoring.

The final column in Table 2 shows estimates of the proportion of total revenue contributed by business advisory services to the accountancy firms. Business advisory services contribute between $20 \%$ and $100 \%$ of accounting firms' total revenue. This finding provides empirical support for the contention that accountants are widening their service portfolio (Doving and Gooderham 2008; Blackburn and Jarvis 2010; Kitching et al. 2011; Jarvis and Rigby 2012) and suggests that business advisory services are emerging as an important source of revenue for accountants working in the SME environment. Most accountants acknowledged that the volume of 'compliance' work was either shrinking, or likely to diminish in the future, and this was creating pressure to broaden their service offerings. One accountant said: "Accountancy practices 
had to move into more areas and I must admit, with the threshold [in the UK] moved up to £1 million turnover, there was outcry and there was this feeling that basically accountants, how arethey going to survive? All this work was disappearing and that didn't happen. It was just redirected in different directions" (A10). Another accountant stated: "So, I can see a time ... when our compliance work is not going to be as good as it is now and we perhaps will be looking for ways of offering [other] services to our clients ... differentiating ourselves and that might be one of the ways we do it" (A06). This future repositioning by accountants was also recognised by SMEs. One owner-manager explained: "You know, most accountancy firms will not make much money on the audits. They make their money from the consultancy and everything that goes with it" (SME08).

All the SME owners indicated that they used a number of external advisors and, despite having existing relationships with their accountants for compliance services, not all SMEs used them additionally as a source of business advice. The final column in Table 1 describes the advisory services SMEs sourced from other professionals. The market for business advice is highly competitive, as highlighted by the following comment from an SME: "I mean ... I get approached. Probably once every two months some business coach or consultant will want to sell their services to me and things like that" (SME02). Although external accountants are already well placed to gain this work because of their ongoing contact while providing compliance services, they clearly need to convince clients to trust that they also have the necessary business expertise to solve the owner-manager's issues.

It is noteworthy that most SME owner-managers interviewed indicated that running a firm was not just about 'doing the business' or making a profit; it was also about fulfilling their personal ambitions and life motivations. This is why personal objectives and family issues often affect business strategies and operations. Such findings are by no means unusual and are especially poignant in the case of micro-enterprises (e.g. Parry, 2010). This point was emphasised by several accountants: "When we talk about 'the SME market', we are talking family businesses and, to provide effective advice, you need to understand the family first. .../... SMEs are about the life of an individual, a couple or $2 / 3$ partners; it's not a clinical business and it's not about the delivery of clinical services and that's why we need trust" (A02). Another accountant stated: "The business of the SME is so deeply embedded in that individual's personal 
wealth ... that it is critical the advisor understands the SME requirements and delivers to those requirements" (A04). Many of the services provided to SME clients by external accountants might therefore be described as business and personal intrinsic services. These services are essential to the well-being of the individual, the business and the family. They also underline the importance of trust in the SME-accountant relationship.

\section{Results - Relationships and Trust}

We begin by reviewing the antecedents of demand for business advice (depicted in the left-hand column in Figure 1), followed by investigating the 'enabling' role of relationships and trust in SMEs' decisions to buy business advice.

Sources of Demand for Business Advice. Antecedent demand factors associated with the demand for business advice by SMEs include firm size, institutional debt, firm age, and growth rate or intention to grow (e.g. Holmes and Nicholls 1989; Kirby et al. 1998; Bennett and Robson 1999; Gooderham et al. 2004; Carey et al. 2005; Berry and Sweeting 2006). The qualitative approach enabled us to develop our understanding of antecedent factors and uncover a number of additional antecedent factors not identified in the extant literature: specifically, economic conditions, environmental turbulence and business life-cycle.

Most SME respondents to this study alluded to what can be generally described as 'environmental turbulence' - usually involving market and/or regulatory change - as an important stimulant for seeking external advice. This gives rise to demand for business advice from firms' external accountants on matters such as structuring or restructuring a business, personal wealth holdings and distributions and purchasing or selling a business. These can be characterised as 'milestone' events that prompt SME owners to seek out the services of external accountants.

Similarly, adverse economic circumstances - both macro-economic and micro-economic - were identified as important drivers of SME demand for business advice. One accountant cited: "problematic economic times" as a significant driver of demand as well as "more competitive industry or a highly-geared business" (A04). Another accountant identified two key drivers: 
"The main one ... I think would be a desire for growth ... The second one would be a financial squeeze" (A03).

All firms face succession or business transfer issues, and their external accountants are often their first port of call: "They might just want to talk about the succession of the business for instance ... We've got an ageing population ... They need to get their firm fit totally to carry on after they retire ... Inheritance tax. I want to give this property to my son, but I don't like his wife. I think they might divorce. How can I do this without her getting involved?”(A08).

A firm's stage in the businesses life cycle was identified as another important factor associated with demand for business advice, although the association appears to be bimodal. One accountant explained: "... demand [for business advice] depends on the phase of the business, maybe a lot of advice early, then when buying or selling a business" (A06). This observation was supported by an SME owner-manager, who said: "Back in the early years if anything happened I'd be on the phone. Different relationship, totally different" (SME04). However, not all accountants agreed. One accountant, highlighting the importance of longerterm relationships in the exchange of business advice, stated: "So I think, generally, it's the more experienced ones [SMEs] that learn how to use [their] advisors ... and the less experienced ones don't" (A02). The three additional demand factors uncovered by the fieldwork are depicted in in the left hand column of Figure 2.

Relationships. Most accountants and SMEs highlighted the importance of relationships in decisions to buy business advice from their external accountants. We asked all participating accountants: "What is the most important factor that causes your clients to stay with you, not only to buy compliance advice, but to go on and buy additional services?" In response, all highlighted the importance of building up a relationship. One expressed it this way: "Relationship, the relationship, there is no doubt the good (accountants) are the ones who maintain the relationship the best" (A02). Highlighting the importance of relationships to SMEs' decisions to rely on their accountants as business advisors, one owner-manager stated: "I'm fortunate [that] I know [the accountant], I've known him for 30 years. I've always been with [the accountant], and I've never been anywhere else really" (SME05). 
The relationship marketing literature highlights the importance of social rapport to a successful business relationship (Berry 1995; Ryals and Payne 2001; Hennig-Thurau 2000). Most accountants and owner-managers indicate the importance of harmonious interpersonal relations - of 'liking' one another - in shaping the relationship. "Likeability. I mean if a client goes to someone, they've got to like them" (A08). Another accountant said: "They feel they can talk to you and, if they feel comfortable with you, then they're more likely to say yes, I can work with this person" (A10). Confirming this sentiment, an SME owner-manager said this: "[My accountant] is very nice, he's decent, he makes you feel good. Is he the best? I don't know. Maybe not, but he's nice to work with. Other people who were supposed to be real hotshots, I couldn't bear sitting with. [It] makes a difference. Much easier to take advice from someone you like than from someone you don't" (SME03).

Social rapport is central to the development of an ongoing relationship, but these relationships are primarily business-based rather than becoming too personal. One ownermanager stated: "Social rapport is important for building that partnership [and] being part of the team" (SME01). He added, however, that "it's less [of] a personal relationship. The primary thing has always been the business side for both of us" (SME01). Another succinctly put it: "You can't have a business relationship with a friend" (SME04). Hence, the majority of ownermanagers and accountants displayed a 'managed' social relationship and this tended not to spill over into socialising. This was epitomised by one owner-manager: "If I bump into [the accountant] on the street, we shake hands and say 'how have you been, how are things going for you, what's happening' $\ldots$ that type of thing. But [socialise] no, I would say it's $90 \%$ a professional relationship" (SME07). An accountant expressed a similar sentiment: "You don't need to socialise outside of work" (A03). Highlighting the importance of social rapport, one SME owner who buys business advice from an accountant stated: "I can pick up the phone and ring [the accountant] and say, 'mate, what's the go with' ... it's very ... not casual, but relaxed" (SME03). While social rapport is necessary for the maintenance of ongoing business relationships, there is little evidence that it directly influences SMEs' decisions to also source business advice from their external accountants.

The relationship marketing literature also highlights the importance of understanding clients' needs through ongoing relationships in order to promote service exchanges (Berry, 1995; 
Ryals and Payne 2001; Hennig-Thurau 2000). All respondents agreed that accountants were competent at providing compliance advice, but had to 'earn' their reputations for broader competency as business advisors. One approach used by accountants to understand their clients' businesses is to make regular visits. One accountant explained: "The key ingredients of caring about your client are taking the time and trouble to understand his business. I visit my clients at their business, and it breaks down the tension" (A05). It's through this type of relationship that SME clients come to understand the potential for their accountants to add value to their businesses: "They [SME clients] begin to understand [over time] that you form part of their success story" (A05). Hence, the argument that proximity and ongoing communications from the local accountant enhance SME commitment by increasing trust (Tan et al 2016) is supported by these findings.

A strong theme emerging from the accountants interviewed was that only after nurturing and developing the relationship over time might SMEs progress from buying compliance services to more broad-ranging advisory services. One accountant explained his approach to nurturing the relationship: “... to build personal relationships takes years ... call it target if you will, I don't like using the term, but if I specifically say 'well that's a family I would like to do business with', then that might take me five years to build the relationship to the point where they have built enough trust and faith in me as a professional advisor" (A03). Continuity of the relationship was identified as important. One accountant explained: "It is about relationships ... many of my clients say to me: 'Because I know I can speak to you and I know you are overseeing my work and therefore I'm not having to tell someone new every year my circumstances, that is a very valuable thing for me and that's the reason why I keep coming to you"” (A06).

Our findings show that, while these relationships are built within the broader framework of institutional trust (Bennett and Robson 1999), it is really the individual who is the focus of the relationship and who facilitates the broadening of the service base. Most accountants emphasise the fact that, although they are surrounded by the trappings of a firm - an institutional environment - it is the individual who builds the relationship and 'cements' that relationship for the firm, after which an SME might purchase additional advisory services. One accountant stated: "The individual is building the relationship, not the firm" (A03). Another noted: "Our 
firm is trying to make it about the organisation, but the truth is it's about the individual relationships" (A02). Even when a particular accountant is no longer the single source of advice in the accounting firm's relationship with an SME, the language used implies the retention of some control in the relationship: "I provide one point of contact and then I use the broader skills of the firm" (A06).

In line with the a priori reasoning in our conceptual model, a consistent theme in our interviews was that relationships were necessary to enable, or connect, SMEs' latent demand for advice with the expertise of their external accountant (see Figure 2). Results suggest social rapport and the accountants' understanding their clients' needs are important conditions that enable the exchange of business advice. A successful relationship allows the accountant to develop an understanding of the client's business needs and for the SME to come to understand the accountant's potential as a business advisor. Social rapport serves to facilitate this understanding. Thus it is argued that relationships assist in reducing information asymmetry and provide greater opportunity for the exchange of business advice. The role of relationships in enabling SMEs latent demand for business advice is depicted in Figure 2.

Trust. The fieldwork explored the role of trust in the SME-accountant relationship explicitly. Although we heard a number of stories regarding the development of trust from both parties, a common pattern emerged: trust is developed over time through ongoing relationships between accountants and SMEs via the provision of compliance services. "I think trust is earned, trust is never given, so you know there has to be a relationship that aids and abets the development of trust before you can actually go down the track." (A03). As another accountant emphasised: "Trust comes from developing the [existing] relationship" (A6). One SME ownermanager who buys a range of business advisory services stated: "Well I just think it's a 30-year relationship where we totally trust what they do and we've always been satisfied with the standard of the service ... we don't question it. ... But it's almost irrational, in some ways, in the sense of the way we buy everything in today's society. Shop around with the internet and all that. But I mean, with this sort of service it's more complex, isn't it?” (SME05).

There was broad consensus among the interviewed SMEs that external accountants are among their most trusted advisors. Accountants' trusted advisor status comes from institutional 
trust (e.g. Bennett and Robson, 1999) and is constantly reinforced by their role in ensuring their clients comply with government regulations, such as taxation laws or the Corporations Act (compliance role). One SME owner stated: "We need that advice to make sure we're sticking with the rules and regulations" (SME02). Another said: "He's your advisor, your compliance keeper and you certainly in business, [are] relying on somebody to make sure you're doing what you've got to do ... That's the whole reason why you're prepared to pay those fees" (SME04). This was recognised by many accountants, who expressed the view that one of their primary roles was to keep their clients clear of regulatory trouble. "I keep their [SME clients] noses clean" (A03).

While trust appears to develop as the relationship evolves, the results suggest we need to be wary of the unequivocal a priori assumption that an already established relationship, developed while providing compliance services, will automatically lead an SME to buy business advice from an external accountant. The next section examines the antecedent elements of trust in our conceptual model: ability (competence), empathy (benevolence), integrity and propensity to trust, and their role in SMEs' decisions to purchase business advice from their external accountants.

\section{Dimensions of Trust: Competence, Empathy and Integrity}

Competence. Accountants and SME owner-managers agree that the core competence of external accountants involves compliance tasks. While all accountants believe they have the capacity to add value to their clients' firms as business advisors, not all SMEs believed that their accountants were competent in providing other types of business advice. For some accountants, compliance work continues to represent the core business. For others, business advisory work has become an important and growing service (see Table 2).

Accountants demonstrate a variety of techniques for communicating their competence as business advisors. Some emphasise hard work and dedication around compliance services. "My hard work and competence [in compliance work] has created trust," said one (A03). One SME owner pointed to the sale of their business (a milestone event), which enabled the accountant to demonstrate business acumen: "The accountant really stood up from the sale transaction viewpoint and showed me their worth" (SME04). One accountant said competence was implied 
from the initial referral: "Referrals imply you are competent" (A05). However, only one SME owner-manager (SME03) stated that he selected his accountant as a business advisor on the basis of reputation for business acumen, not compliance work.

Industry knowledge was identified as critical to establishing the competence of accountants as business advisors. One accountant highlighted the importance of industry knowledge as a particular field of expertise. "Once you get known in the industry ... people walk in wanting to come to you" (A10). This can, however, cut both ways. One owner-manager who made limited use of his accountant as a business advisor argued accountants were 'out of touch' with his industry, and that he had not received value for money on past business advisory services provided by external accountants. (SME04). He stated: "Most of the accounting firms ... they'll have their little specialist ... but I don't know! So many of them are out of touch. They've just got no handle on it. No handle on the real world ... and I got sick of up-skilling. Getting them up to speed for them to make comments, so I got sort of frustrated ... paying a couple of thousand dollars to have a chat and not getting anything from it" (SME04). He highlighted the importance of detailed industry knowledge: "They [the accountant] could be more specialised in certain areas that can truly offer advice rather than trying to be a jack of all trades" (SME04).

Consistent with the assertion that external accountants have increasingly developed into multi-disciplinary service providers (see, for example, Blackburn and Jarvis 2010; Fogarty et al. 2006; Greenwood et al. 2002; Jarvis and Rigby 2012), a number of accountants expressed the view that they did not need to possess detailed industry or specialised knowledge. Rather they simply needed to know where to source the required knowledge. One accountant from a $2^{\text {nd }}$ tier accounting firms used a supply-chain analogy, saying "accountants are a distribution network", implying that if they do not possess the requisite expertise, they will find that knowledge for the client (A05). Another accountant indicated that accessing business expertise often meant referring SME clients to others within their businesses: "New standards require more specialisation, so we give more work to other partners who specialise in a particular area" (A03). Another accountant said: "We have one single contact point, but then use the broad skills of the firm ... we say to our clients, 'we're your one-stop shop'. Our clients come to us if they need any recommendations to anything else and even very specialist work that we don't carry out we will 
go and find it" (A08). The largest $2^{\text {nd }}$ tier accounting firms in our sample (A06) had established a dedicated account manager who sought to direct SME clients to the broad range of business expertise within the firm. Another accounting practice (A08) had focused on increasing their business advice competency, while at the same time outsourcing their compliance work to India.

Overall, the results show that competence or business acumen of an external accountant is critical before an SME will consider buying business advice. While all external accountants perceive themselves as having the necessary skills to provide useful business advice, ownermanagers expressed mixed views on this issue. This is consistent with a number of prior studies, which suggested that external accountants do not always have the business expertise (competence) necessary if they are to add value as business advisors (Marriott et al. 2008; Burke and Jarratt 2004; Deakins et al. 2001). Many SMEs require their accountants to have detailed industry expertise before considering them as potentially useful business advisors. It may be asserted that an expectations gap appears to exist between the needs of SME owners and the supply capabilities of many external accountants.

Empathy. Empathy involves the accountant understanding and genuinely caring about the client's interests. As one accountant noted: "We have an obligation morally and ethically to represent their best interests" (A04). Another said: "No matter how well I get on with someone, if I don't do the right thing by them ... they wouldn't hang around." (A06). Elaborating on how to develop empathy, one accountant explained: "You show you care ... well to me it's just common sense. I return calls. I speak to them and I give them my honest opinion about everything" (A07). Another accountant said: "Generally we're not really competing on price. What you're competing on is almost empathy" (A10). With direct reference to selling business advice, another accountant noted: "Unless you have that empathy ... then it's never going to happen" (A11). One of the advantages that many external accountants have is their size: they themselves, as SMPs, can relate to the plight of SMEs and the demands of running a smaller firm.

The interviews revealed a common view that empathy assists accountants to come closer to their clients and thus to develop a deeper understanding of their business concerns. One accountant said: "A lot of it is very personal to their business and that's why you need this 
relationship trust because it's that knowledge of their business and their life" (A01). Another accountant stated: "If they've got a problem we talk it through ... they have got nobody on their side. They can't talk to the bank because the problem might be the bank. So we are somebody who's on their side" (A08). An SME owner-manager similarly stressed the importance of empathy to the choice of advisor: "I need someone who understands small business and understands the pressures and workloads of the person [who] runs the company" (SME02).

The fieldwork shows that empathy is a critical ingredient in successful client relationships, but it does not assure that an SME will source business advice from their accountant. Accountants with empathy are perceived by SME owner-managers to genuinely care about their businesses and personal needs, making them more receptive to business advice when offered by accountants. Further insight regarding the role of empathy is that it allows accountants to come closer to their SME clients and thus come to understand their deeper business (and sometimes related personal) problems. In the absence of empathy, an SME is unlikely to rely on the advice of their accountant. Consistent with the prediction in our conceptual model, results suggest empathy is a necessary condition that plays an indirect role in enabling accountants to connect with SMEs' latent demand for business advice.

Integrity. All interviewees maintained that integrity was a critical dimension in the accountant-SME relationship. One accountant said: "If the client does not believe we have integrity, we would not hold them', (A04). The importance of integrity was highlighted by many SMEs. One stated: "As a person I feel integrity is very important" (SME05). Another pointed to the fundamental role of integrity to the ongoing accountant-SME relationship. "Trust is vital to who we are and what we do. It underpins everything we do internally and externally, so I guess integrity would probably be number one if I had to rank them because without that, you start to question everything. It doesn't matter if they've got ability if they don't have integrity" (SME01). Another accountant supported this view: "I would put [integrity] higher than ability" (A06).

When discussing integrity, the discussion frequently turned to honesty, which is perceived to be closely related to integrity. Honesty is one of the most valued qualities in society. If someone is honest they are by implication trustworthy. The primary compliance role of 
external accountants requires them to be honest. As previously discussed, one role of external accountants is to ensure that their clients are in compliance with the law. It is this very relationship of "required honesty" that gives prominence to trustworthiness in the accountantclient relationship.

However, as was the case with empathy, results suggest that integrity is a critical ingredient in successful client relationships, but it does not ensure that an SME will source business advice from their own accountant. Consistent with the prediction in our conceptual model, results suggest integrity does not directly influence SMEs' decisions to buy business advice from their accountants. This is because integrity is fundamental to accountants' ability to retain their clients, even for basic compliance work. This linkage is depicted by the arrow joining relationships and trust is in Figure 2.

Owner-Manager's Propensity to Trust. Mayer et al. (1995) argued that a trusting nature, or a greater propensity to trust, was akin to a personality trait. Our results suggest that the personalities of owner-managers can influence the extent to which they seek and purchase external business advice. One accountant respondent stated: "The driver of demand is ... the personality of the SME owners being either self-directed people or people who seek advice to assist them [to] make decisions" (A04). Most owner-managers appeared to conform to one or the other of these characterisations. The group of self-directed individuals' were more confident about relying on their own judgements and were therefore less likely to buy ongoing advice from their accountants, believing that they or their friends and associates possessed the necessary business expertise. This group would only seek advice, in addition to traditional compliance-type services, in response to an imposed change (e.g., regulatory) or significant event (e.g., sale of business) (SME02, SME04, SME08). The second group appear to have a more trusting nature. These are individuals who like to validate decisions by seeking corroborating advice. This group takes longer to develop their confidence in a particular decision path. They tend to make more considered decisions and are thus more likely to seek ongoing business advice as part of the process of seeking information to guide or corroborate their decisions (SME01, SME03, SME05, SME07) $)^{5}$.

\footnotetext{
${ }^{5}$ SME06 fell into neither category.
} 
These two SME types are illustrated by the following contrasting attitudes. SME04 stated: “Accountants did offer other services but I didn't want them". An accountant reinforced this assertion: "[Some] SME clients [are] very driven, they know it all, a lot of them are still mainly one owner, they have created the business, it is hard for them to let go" (A01). Another accountant observed that "those SME owners that are a bit unsure of themselves" were more likely to seek his advice (A07).

Consistent with the prediction in our conceptual model, results suggest SME ownermanagers' propensity to trust plays an indirect role in enabling accountants to connect with latent demand for business advice. SME owner-managers with a more trusting nature (i.e. a greater propensity to trust) are more open to buying business advice, though business advice need not be sourced from the external accountant. For those individuals with a less trusting nature, the accountant needs to very clearly demonstrate their competence and empathy before business advice is sought.

A limitation of the fieldwork results is that it is based on a non-random and limited sample of accountants and SMEs. A larger-sample will enable empirical validation of the contention that relationships and trust are necessary conditions for enabling (or mediating) latent demand for business advice. Future research should consider a larger-scale study to explore variation in decision-making by SMEs and to better understand how different contexts within which SMEs operate helps explain variation in their decision. Our fieldwork results also call into question some of the previously held assumptions regarding the development of accountant-SME relations, but these findings need verification via large-scale empirical analysis.

\section{Summary and Discussion}

This paper develops and substantiates with fieldwork a conceptual framework explaining the role of relationships and trust in the SME's decision to purchase business advice from its external accountant. Our fieldwork shows that relationships and trust, rather than being antecedents of demand for business advice, are in fact necessary conditions for activating (or mediating) latent demand. Although demand factors such as age of the business or intention to grow will determine an SME's ex ante need for advice, we confirm that it is the enabling or mediating factors of relationships and trust that determine whether business advice is actually taken up. 
Corroborating recent studies (Viljamaa 2011; Tan et al., 2016), SME owner-managers demonstrate a discerning approach to the type of advice they require and to the sources from which they will purchase advice. SME owners indicated that they used a number of external advisors and, despite having existing relationships with their accountants for compliance services, not all SMEs used them additionally as a source of business advice.

The development of a unique relationship between the client and accountant is necessary to enable the SMEs' latent demand for advice. As a result of the intangible nature of professional services, accounting services exhibit credence attributes and are likely to be prone to ex ante information problems. Thus a successful relationship will allow an accountant to develop an understanding of the client's business needs and for the SME to come to understand the potential of their accountant as a business advisor. Accordingly, ongoing interaction between the client and supplier is one important way of overcoming information asymmetries. While social rapport is necessary for the maintenance of ongoing business relationships, there is no evidence to suggest that it directly influences SMEs' decisions to source business advice from their external accountants. Relationships, therefore, have boundaries and are kept strictly professional. At the same time, they play a role in reducing information asymmetry concerning the accountants' competence and the SMEs' latent demand for advice, providing greater opportunity for the exchange of business advice.

Consistent with prior research that finds trust is built over time in client-supplier relationships (e.g. Gounaris and Venetis 2002; Denize and Young 2007; Welter 2011), our fieldwork reveals that ongoing relationships between accountants and SMEs, developed over time while providing compliance services, contributes to the building of trust. There is consensus amongst SMEs that external accountants are among their most trusted advisors. However, the $a$ priori assumption that already-established relationships between accountants and their SME clients developed while providing compliance services will lead SMEs to buy business advice is not confirmed. In other words, trust is bounded within specific areas of competency and is not easily transferable or extended to other advisory areas.

The competence or business acumen of an external accountant is critical before an SME will consider buying business advice. While all interviewed external accountants perceived 
themselves as having the necessary competence to provide useful business advice, SME ownermanagers expressed mixed views on their capability. This is consistent with a number of prior studies that suggest external accountants do not always have the business expertise (competence) necessary to add value as business advisors (Marriott et al. 2008; Burke and Jarratt 2004; Deakins et al. 2001). The fieldwork also revealed the critical importance of industry-based knowledge to establishing the competence of accountants as business advisors. Ostensibly, although external accountants may be well placed to offer business advisory services to their SME clients on the back of compliance services, and indeed are better placed than most other providers (Mole 2002; Tan et al., 2016), they need to convince clients that they have the necessary business expertise beyond their compliance capabilities. The fieldwork, therefore, highlights that an expectation gap exists between SME owners' perceptions and external accountants' ability to provide advice.

Empathy (benevolence) is critical to a successful client relationship, but it does not ensure that an SME will source business advice from their accountant, suggesting that it plays an indirect role in enabling accountants to connect with SMEs' latent demand for business advice. When an accountant is perceived by their SME client as genuinely caring about their business and personal needs (empathy), they can get closer to their client and thus come to understand their deeper business (and sometimes related personal) problems. In the absence of empathy, an owner-manager is unlikely to rely on the advice of their accountant. These results demonstrate that SME owners exhibit both calculative and affective trust behaviours (e.g. Tyler and Stanley 2007); that is, the relationship with their accountants is based not only on diminishing information asymmetries and uncertainties, but also on emotional inputs derived from repeated interactions and information acquired over time.

Both accountants and SME owner-managers agreed that integrity was a critical dimension of trust and that, without integrity, the accountant would not retain the SME client. As was with empathy, integrity does not ensure that an SME will source business advice from their accountant and therefore it does not directly influence SMEs' decisions to buy business advice. This is because integrity is fundamental to accountants' ability to retain their clients, even for basic compliance work. 
The analysis suggests an SME owner-managers' propensity to trust is a necessary condition that plays an indirect role in enabling accountants to connect with SMEs' latent demand for business advice. SME owner-managers with more trusting natures (i.e., a greater propensity to trust) are more open to buying business advice, although business advice need not be sourced from the external accountant. For those individuals with less trusting natures, the accountants need to very clearly demonstrate their competence and empathy before business advice is sought.

Our fieldwork identified a number of approaches accountants are using to communicate their competence as business advisors. Some accountants indicated they had created forums and information meetings to keep their clients up to date with changes. In turn, these forums allowed accountants to display their competence potentially leading to further work. Because of the difficulty of accountants developing detailed industry knowledge across multiple industries, smaller accounting practices in particular might restructure their organisations to increase access to detailed industry knowledge. This may involve nurturing a multi-disciplinary network of suppliers, organised around industry expertise, with the accounting practice itself becoming more of a referral hub. Future research might investigate alternative approaches for external accountants to promote their expertise as business advisors.

Our results have important theoretical and practical implications. Theoretically, the development of our conceptual model clarifies how relationships and trust are used by both the accountant and client to overcome credence issues and ex ante information problems. Indeed, the conceptual model distinguishes, for the first time, the antecedent factors of demand for business advice from the enabling roles of relationships and trust. Further, our fieldwork has yielded a number of important new leads and insights into the complex behaviour and motivations of SME managers and owners when it comes to their consideration of whether to purchase business advice from external accountants. Specifically, our research uncovered significant insights into how specific personality traits of SME owner-managers can influence decisions to purchase external business advice. This in turn contributes to a deeper and more nuanced understanding of the role of personal trust in the accountant-client relationship, particularly as it relates to decisions to purchase business advice. Our findings of an expectation gap concerning the competence of the accountant to provide business advice highlights the need for the profession to 
develop initiatives to strengthen the accountant's business acumen and industry based business knowledge. External accountants are particularly well placed to expand their service offerings to support SMEs, but the challenge is to close the expectation gap by convincing SME clients that they have the expertise to support business success as well as ensuring that the accountant possesses the necessary skills to add value to their clients.

By materially expanding knowledge and understanding of the complex array of factors influencing decisions by SMEs to purchase business advice from their accountants, our findings could assist accountants - particularly smaller practices - when refining their business models in future with a view to promoting a greater uptake of business advisory services. This is a particularly pertinent consideration for accountants at a time when demand for their traditional compliance services is in decline all over the world. 


\section{References}

Accounting Professional and Ethical Standards, February. (2008), "Compiled APES 110 Code of Ethics for Professional Accountants", in Handbook of International Auditing, Assurance and Ethics Pronouncements, International Ethics Standards Board for Accountants, International Federation of Accountants (IFAC), New York.

Achrol, R.S. (1997), "Changes in the theory of interorganizational relations in marketing: toward a network paradigm", Journal of the Academy of Marketing Science, 25(2), 56-71.

American Institute of Certified Practising Accountants (AICPA). (2011), CPA horizons for 2025: A road map for the future. Journal of Accountancy, December 212(6), 44-47.

Andaleeb, S.S. (1992), "The trust concept: research issues for channels of distribution", Research in Marketing, 11, 1-34.

Anderson, E. and B.A. Weitz (1989), "Determinants of continuity in conventional industrial channel dyads", Marketing Science, 8(4), 310-323.

Anderson-Gough, F., C. Grey, and K. Robson (2002), “Accounting professionals and the accounting profession: linking conduct and context", Accounting and Business Research, $32(1), 41-56$.

Australian Bureau of Statistics. (2001), “The Australian Business Register, June 2001. ABS Catalogue No. 1369.0.55.001, Australian Government Publishers, Canberra.

Barney, J.B. and M.H. Hansen (1994), "Trustworthiness as a source of competitive advantage", Strategic Management Journal, 15, 175-190.

Bennett, R. J. and C. Smith (2004), "The selection and control of management consultants by small business clients", International Small Business Journal, 22, 435-462.

Bennett, R.J. and P.J. Robson (1999), "The use of external business advice by SMEs in Britain”, Enterprise and Regional Development, 11,155-180

Berry, L.L. (1995), "Relationship marketing of services - growing interest, emerging perspectives", Journal of the Academy of Marketing Science, 23(Fall), 4, 236-245.

Berry, A.J. and R. Sweeting (2006), "The effect business advisors on the performance of SMEs", Journal of Small Business and Enterprise Development, 13(1), 33-47.

Blackburn, R. and R. Jarvis (2010), "The role of small and medium practices in providing business support to small- and medium-sized enterprises", Small and Medium Practices Committee Information Paper, International Federation of Accountants, New York, April, 2010.

Blair, E.S. and T.M. Marcum (2015), "Heed Our Advice: Exploring How Professionals Guide Small Business Owners in Start-Up Entity Choice”, Journal of Small Business Management, 53(1), 249-265.

Burke, G.I., and D.G. Jarratt (2004), "The influence of information and advice on competitive strategy definition in small- and medium-sized enterprises", Qualitative Market Research: An International Journal, 7(2), 126-138.

Busco, C., A. Riccaboni, and R.W. Scapens (2006), "Trust for Accounting and Accounting for Trust", Management Accounting Research, 17(1), 11-41.

Carey, P. and G.A. Tanewski (2016), "The provision of business advice to SMEs by external accountants", Managerial Auditing Journal, 31(3), 290-313.

Carey, P., R. Simnett and G.A. Tanewski (2005), "Providing business advice to small and medium sized enterprises", Report prepared for CPA Australia, July 2005. 
Chua W. F. (1996), "Issues in substantive areas of research: Field research in accounting”, in A.J. Richardson (Ed.), Research Methods in Accounting: Issues and Debates. Research Monograph Number 25, CGA Canada Research Foundation, Vancouver.

Claycomb, C. and C.L. Martin (2002), "Building customer relationships: an inventory of service providers' objectives and practices”, Journal of Services marketing, 16(7), 615-635.

Covaleski, M., M. Dirsmith, J. Heian and S. Samuel (1998), "The calculated and the avowed: techniques of discipline and struggles over identity in Big 6 public accounting firms", Administrative Science Quarterly, 43(June), 298-327.

Cowton, C.J. (2009), "Accounting and the ethics challenge: Remembering the professional body", Accounting and Business Research, 39(3), 177-189.

Crosby, L.A., K.R. Evans and D. Cowles (1990), "Relationship quality in services selling: an interpersonal influence perspective", Journal of Marketing, 54(July), 68-81.

Curran, J. and R.A. Blackburn (1994), Small firms and local economic networks: The death of the local economy? London: Paul Chapman/Sage.

Deakins, D., D. Logan and L. Steele (2001), "The Financial Management of the Small Enterprise", ACCA Research Report No. 64, The Association of Chartered Certified Accountants, Certified Accountants Educational Trust, London.

Denize, S. and L. Young (2007), "Concerning trust and information", Industrial Marketing Management, 36, 968-982.

Department for Business Innovation and Skills. (2009), "Enterprise Directorate Analytical Unit”, available at: http://www.berr.gov.uk/whatwedo/enterprise/enterprisesmes/research-andstatistics/statistics/page38573.html (accessed July 2014).

Dirsmith, M., J. Heian and M. Covaleski (1997), "Structure and agency in an institutionalized setting: the application and social transformation of control in the Big Six", Accounting Organizations and Society, 22(January) 1, 1-17.

Doving, E. and P.N. Gooderham (2008), "Dynamic capabilities as antecedents of the scope of related diversification: the case of small firm accountancy practices", Strategic Management Journal, 29(8), 841-857.

Dyer, L. M., and C. A. Ross (2007). “Advising the Small Business Client," International Small Business Journal, 25(2), 130-149.

Edwards, P., S. Sengupta and C. Tsai (2010), "The context-dependent nature of small firms' relations with support agencies: A three-sector study in the UK”, International Small Business Journal, 28(6), 543-565.

Ferguson, L. (2012), “Gaining (from) your clients' trust”, Journal of Accountancy, May 213(5), $38-43$.

Fogarty, T.J., V.S. Radcliffe, and D.R. Campbell (2006), "Accountancy before the fall. The AICPA vision project and related professional enterprises", Accounting Organizations and Society, 31, 1-25.

Gooderham, P.N., A. Tobiassen, E. Doving, and O. Nordhaug (2004), “Accountants and sources of business advice for small firms", International Small Business Journal, 22(1), 5-22.

Gounaris, S.P. and K. Venetis (2002), "Trust in industrial service relationships: behavioural consequences, antecedents and the moderating effect of the duration of the relationship", Journal of Service Marketing, 16(7), 636-655.

Greenwood, R., R. Suddaby and C.R. Hinings (2002), "Theorizing change: The role of professional associations in the transformation of institutional fields", Academy of Management Journal, 45(1), 58-80. 
Grey, C. (1998), "On being a professional in a Big Six firm”, Accounting Organizations and Society, 23(5/6), 569-587.

Grönroos, C. (1990), Service Management and Marketing: Managing the Moments of Truth in Service Competition, Lexington Books, Lexington, MA.

Guest, G., A. Bunce and L. Johnson (2006), "How many interviews are enough?: An experiment with data saturation and variability", Field Methods, 18(1), 59-82.

Håkansson, H. (Ed.). (1982), International Marketing and Purchasing of Industrial Goods, Wiley, New York, NY.

Hartstein, B.D. (2013), "Certified public accountants as future "trusted business advisors" - and how to engage them", Journal of Financial Service Professionals, November, 35-39.

Hennig-Thurau, T. (2000), "Relationship quality and customer retention through strategic communication of customer skills", Journal of Marketing Management, 16(1-3), 55-80.

Holmes, S., \& D. Nicholls (1989), "Modelling the accounting information requirements of small businesses", Accounting and Business Research, 19(74), 143-150.

Huggins, R. and A. Johnston (2010), "Knowledge flow and inter-firm networks: The influence of network resources, spatial proximity and firm size", Entrepreneurship and Regional Development, 22(5), 457-488.

ICPAS-CPA Australia Roundtable (2013), "Leveraging on Advisory Services for Business Growth", Institute of Certified Public Accountants of Singapore (ICPAS) and CPA Australia, June 2013.

Jarvis, R. and M. Rigby (2012), "The provision of human resources and employment advice to small and medium-sized enterprises: The role of small and medium-sized practices of accountants", International Small Business Journal, 30(8), 944-956.

Kirby, D.A. and S.H. King (1997), "Accountants and small business development: Filling the expectation gap", The Services Industries Journal, 17(2), 294-304.

Kirby, D. A., B. Najak, and F. Greene. (1998), "Accounting for growth: Ways accountants can add value to small business", The Research Board, ICEW, London.

Kitching, J., E. Kasperova, R. Blackburn, and J. Collis (2011), "Small company abbreviated accounts: A regulatory burden or a vital disclosure", Institute of Chartered Accountants of Scotland. ASBN. 978-1-904574-80-4

Kramer, R.M. and T.R. Tyler (Eds). (1996), Trust in Organizations: Frontiers of Theory and Research, London: Sage.

Kuzel, A. (1992), "Sampling in qualitative inquiry", in Crabtree, B. and W. Miller (Ed.),.Doing Qualitative Research, Sage, Newbury Park, CA, pp. 31-44.

Lambert, R.A. (2001), "Contracting theory and accounting", Journal of Accounting and Economics, 32, 3-87.

La Porta, R., F. Lopez-de-Silanes, A. Shleifer and R.W. Vishny (2000), "Investor protection and corporate governance", Journal of Financial Economics, 58(1-2), 3-27.

Lee, J.S. and Y. Kwon (2014), "Exploring Key Factors of Application Software Services and Their Relationships for Organizational Success in SMEs", Journal of Small Business Management, 52(4), 753-770.

Lewicki, R.J., D.J. McAllister and R.J. Bies (1998), “Trust and distrust: new relationships and realities", Academy of Management Review, 22(3), 438-458.

Martin, C. (2004), "Accountancy practices and the provision of ownership succession advice", ACCA Research Report RR85, ACCA, London. 
Mariott, N., and P. Mariott. (2000), "Professional accountants and the development of a management accounting service for small firms: Barriers and possibilities", Management Accounting Research, 11(4), 475-495.

Marriott, N., P. Marriott, J. Collis and D.D. Son (2008), "The Accountant and the Provision of Financial Advice to UK Smaller Companies", British Accounting Association Annual Conference, Blackpool, April.

Mayer, R.C., J.H. Davis, and F.D. Schoorman (1995), "An integrative model of organizational trust", Academy of Management Review, 20(3), 709-734.

Miles, M. B. and A. M. Huberman (1994), Qualitative Data Analysis. Sage Publications, Thousand Oaks, CA.

Mole, K. (2002), "Business Advisors' Impact on SMEs: An Agency Theory Approach”, International Small Business Journal, 20(2), 139-162.

Möllering, G. (2002), "Perceived trustworthiness and inter-firm governance: empirical evidence from the UK printing industry", Cambridge Journal of Economics, 26(2), 139-160.

Moorman, C., R. Deshpande and G. Zaltman (1993), "Factors affecting trust in market research relationships", Journal of Marketing, 75(1), 81-101.

Nooteboom, B. (2002), Trust, Forms, Foundations, Functions, Failures and Figures. Edward Elgar, London.

Parker, L., (2001), "Back to the future: The broadening accounting trajectory", British Accounting Review, 33, 421-453.

Price, L.L., E.J. Arnould and P. Tierney (1995), "Going to extremes: managing and assessing provider performance", Journal of Marketing, 59(April), 83-97.

Professional Oversight Board. (2010), Key Facts and Trends in the Accountancy Profession, Financial Reporting Council, London, June.

Puffer, S.M., D.J., McCarthy and M. Boisot (2010), "Entrepreneurship in Russia and China: The impact of formal institutional voids", Entrepreneurship Theory and Practice, 34, 441-467.

Roslender, R. (1992), Sociological Perspectives on Modern Accountancy, Routledge, London.

Ryals, L. and A. Payne (2001), "Customer relationship management in financial services: towards information-enabled relationship marketing”, Journal of Strategic Marketing, 9(1), 3-27.

Schoorman, F.D., R.C. Mayer \& J.H. Davis (2007), "The integrative model of organizational trust: Past, present, and future", Academy of Management Review, 32, 344-354.

Stone, G. (2015),"Power, dependence and frustration", Meditari Accountancy Research, 23(3), $250-275$.

Stone, G. (2011), “Let's talk: adapting accountants' communications to small business managers' objectives and preferences", Accounting, Auditing \& Accountability Journal, 24(6), 781-809.

Tan, L.M., Braithwaite, V., and Reinhart, M. (2016). "Why do small business taxpayers stay with their practitioners? Trust, competence and aggressive advice", International Small Business Journal, 34(3), 329-344.

The Economist. (2010), "A conflict of interest. A question of holding accountants to account", October 16, 70 .

Tomkins, C. (2001), "Interdependencies, trust and information in relationships, alliances and networks", Accounting, Organizations and Society, 26, 161-191.

Tyler, K. and E. Stanley (2007), "The role of trust in financial services business relationships", Journal of Services Marketing, 21(5), 334-344. 
U.S. Census Bureau (Census). (2009), “A Profile of U.S. Exporting Companies, 2006-07”, April 9, 2009.

U.S. Small Business Administration (SBA). (2014), "Office of Advocacy. Frequently Asked Questions", available at: http://www.sba.gov/category/advocacy-navigation-structure/faqs (accessed March 2014).

Viljamaa, A. (2011), 'Exploring small manufacturing firms' process of accessing external expertise. International Small Business Journal 0266242610390595, first published on July 18, 2011 as doi:10.1177/0266242610390595

Welter, F. (2011), "Contextualizing entrepreneurship: Conceptual challenges and ways forward", Entrepreneurship Theory and Practice, 35, 165-184.

Welter, F. and D. Smallbone (2006), Exploring the role of trust in entrepreneurial activity. Entrepreneurship Theory and Practice, 30, 465-475.

Zand, D.E. (1972), "Trust and managerial problem solving”, Administrative Science Quarterly, 17, 229-239. 


\section{Figure 1. Conceptual Framework for Business Advice Derived from the Literature}

\section{$\underline{\text { Ex-Ante Demand Factors }}$}

\begin{tabular}{|c|}
\hline Size \\
\hline Age \\
\hline 2 \\
\hline 3 \\
\hline Debt \\
\hline 4 \\
\hline \begin{tabular}{c} 
Growth Rate \\
\\
\hline
\end{tabular} \\
\hline 5 \\
Intention to \\
Grow \\
\hline
\end{tabular}

$\underline{\text { Relationships and Trust }}$

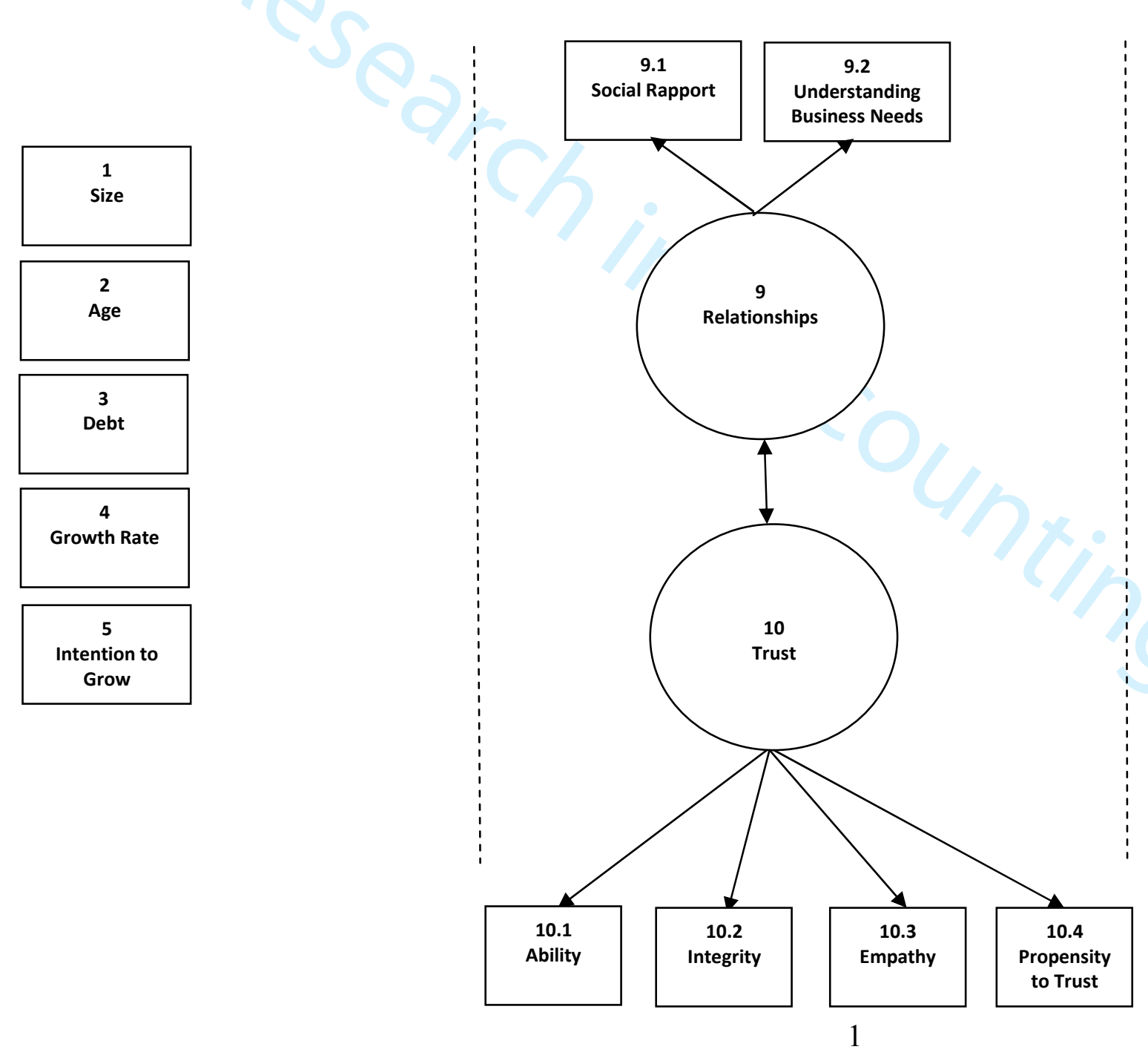

\section{$\underline{\text { Dependent Variable }}$}

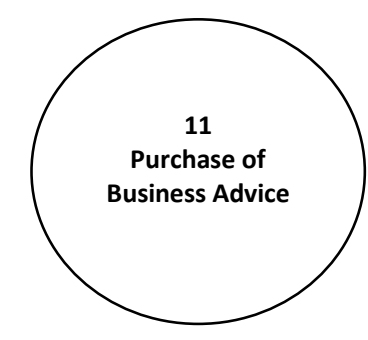


Qualitative Research in Accounting and Management

Page 36 of 41

$$
\begin{aligned}
& 1 \\
& 2 \\
& 3 \\
& 4 \\
& 5 \\
& 6 \\
& 7 \\
& 8 \\
& 9 \\
& 10 \\
& 11 \\
& 12 \\
& 13 \\
& 14 \\
& 15 \\
& 16 \\
& 17 \\
& 18 \\
& 19 \\
& 20 \\
& 21 \\
& 22 \\
& 23 \\
& 24 \\
& 25 \\
& 26 \\
& 27 \\
& 28 \\
& 29 \\
& 30 \\
& 31 \\
& 32 \\
& 33 \\
& 34 \\
& 35 \\
& 36 \\
& 37 \\
& 38 \\
& 39 \\
& 40 \\
& 41 \\
& 42 \\
& 43 \\
& 44 \\
& 45 \\
& 46 \\
& 47 \\
& 48 \\
& 49 \\
& 50 \\
& 51 \\
& 52 \\
& 53 \\
& 54 \\
& 55 \\
& 56 \\
& 57 \\
& 50
\end{aligned}
$$


Table 1. SMEs Interviewed: Business Advice Purchased from External Accountant

\begin{tabular}{|c|c|c|c|c|}
\hline Company & $\begin{array}{l}\text { Sector, Industry, } \\
\text { Country }\end{array}$ & $\begin{array}{l}\text { Size: } \\
\text { Employees }\end{array}$ & $\begin{array}{l}\text { Business Advisory Services } \\
\text { Purchased from External } \\
\text { Accountant }\end{array}$ & $\begin{array}{l}\text { Business Advisory } \\
\text { Services, Other } \\
\text { Advisers } \\
\end{array}$ \\
\hline SME01 & $\begin{array}{l}\text { Wholesale/ } \\
\text { Importer consumer } \\
\text { products } \\
\text { Australia }\end{array}$ & 30 & None & $\begin{array}{l}\text { Financial Planning } \\
\text { (Investments) } \\
\text { Mentoring, coaching, } \\
\text { strategic planning, } \\
\text { benchmarking, Para- } \\
\text { legal, human resource } \\
\text { support. }\end{array}$ \\
\hline SME02 & $\begin{array}{l}\text { Manufacturing/Wholesal } \\
\text { e/Exporting Unique } \\
\text { Australian Clothing } \\
\text { Australia }\end{array}$ & 80 & $\begin{array}{l}\text { Acquisition and New Business } \\
\text { advice. Financial Modelling } \\
\text { Assisting with Bank Finance }\end{array}$ & $\begin{array}{l}\text { Textile Industry } \\
\text { Consulting Group } \\
\text { HR, Marketing }\end{array}$ \\
\hline SME03 & $\begin{array}{l}\text { Packaging Food and } \\
\text { Drugs } \\
\text { Australia }\end{array}$ & 50 & Business Structuring & $\begin{array}{l}\text { Task Orientated } \\
\text { Marketing, } \\
\text { Production }\end{array}$ \\
\hline SME04 & $\begin{array}{l}\text { Retail and Wholesale } \\
\text { Australia }\end{array}$ & 180 & Sale of Business & $\begin{array}{l}\text { Mentoring/Coach } \\
\text { HR }\end{array}$ \\
\hline SME05 & $\begin{array}{l}\text { Personal Service - } \\
\text { Hairdressing } \\
\text { UK }\end{array}$ & 20 & $\begin{array}{l}\text { Property and Finance Advice } \\
\text { Milestone Events, payroll, HR }\end{array}$ & None \\
\hline SME06 & $\begin{array}{l}\text { Retail and Wholesale, } \\
\text { Manufacturing Service - } \\
\text { Bespoke Clothing } \\
\text { Sampling } \\
\text { UK }\end{array}$ & 7 & Structuring, HR & $\begin{array}{l}\text { Regional Business } \\
\text { Centre - Various }\end{array}$ \\
\hline SME07 & $\begin{array}{l}\text { Service B-To-B -Design } \\
\text { \& Marketing } \\
\text { UK }\end{array}$ & 5 & $\begin{array}{l}\text { Financial Advice, General } \\
\text { Business Advice }\end{array}$ & None \\
\hline SME08 & $\begin{array}{l}\text { Manufacturing, } \\
\text { Wholesale, Retail - } \\
\text { furniture and textiles } \\
\text { UK }\end{array}$ & 86 & None & Payroll, Marketing \\
\hline
\end{tabular}


Table 2. Accountants Interviewed: Provision of Services to SMEs

\begin{tabular}{|c|c|c|c|c|}
\hline $\begin{array}{l}\text { Accountant } \\
\text { Interviewed }\end{array}$ & $\begin{array}{l}\text { Size of Accountancy } \\
\text { Firm } \\
\text { Country }\end{array}$ & Interviewees & $\begin{array}{l}\text { Types of Business Advisory } \\
\text { Services } \\
\text { Provided by Firm }\end{array}$ & $\begin{array}{l}\text { Proportion of } \\
\text { Firm Revenue } \\
\text { Contributed by } \\
\text { Business Advisory } \\
\text { Services }\end{array}$ \\
\hline A01 & $\begin{array}{l}2^{\text {nd }} \text { Tier } \\
\text { Australia }\end{array}$ & $\begin{array}{l}\text { Partner- } \\
\text { SME } \\
\text { Accounting } \\
\text { Services }\end{array}$ & $\begin{array}{l}\text { Financial Management, } \\
\text { Planning, Forecasting, } \\
\text { Succession planning, } \\
\text { Superannuation, Asset } \\
\text { Protection }\end{array}$ & $40 \%$ \\
\hline A02 & $\begin{array}{l}2^{\text {nd }} \text { Tier } \\
\text { Australia }\end{array}$ & $\begin{array}{l}\text { Partner - } \\
\text { SME Private } \\
\text { Clients }\end{array}$ & $\begin{array}{l}\text { Banking, Wealth Creation, } \\
\text { Succession Planning }\end{array}$ & $40 \%$ \\
\hline $\mathrm{A} 03$ & $\begin{array}{l}2^{\text {nd }} \text { Tier } \\
\text { Australia }\end{array}$ & $\begin{array}{l}\text { Partner - } \\
\text { SME Audit }\end{array}$ & $\begin{array}{l}\text { Financial Statements, Valuation, } \\
\text { Business Sale and Purchase, } \\
\text { Due Diligence }\end{array}$ & $20 \%$ \\
\hline A04 & $\begin{array}{l}2^{\text {nd }} \text { Tier } \\
\text { Australia }\end{array}$ & $\begin{array}{l}\text { Partner - } \\
\text { SME Private } \\
\text { Clients }\end{array}$ & $\begin{array}{l}\text { Corporate Advisory, Private } \\
\text { Wealth Advisory, Investment } \\
\text { Strategy, Succession planning, } \\
\text { Business Sale and Purchase } \\
\text { Forensic Accounting }\end{array}$ & $60 \%$ \\
\hline A05 & $\begin{array}{l}2^{\text {nd }} \text { Tier } \\
\text { Australia }\end{array}$ & $\begin{array}{l}\text { Partner- } \\
\text { SME Private } \\
\text { Clients }\end{array}$ & $\begin{array}{l}\text { Structuring, Superannuation, IT, } \\
\text { HR, Finance Brokering, } \\
\text { Providing Networking }\end{array}$ & $25 \%$ \\
\hline A06 & $\begin{array}{l}2^{\text {nd }} \text { Tier } \\
\text { Australia }\end{array}$ & $\begin{array}{l}\text { Partner- } \\
\text { SME Private } \\
\text { Clients }\end{array}$ & $\begin{array}{l}\text { Purchase And Sale of Business, } \\
\text { Structuring, Financial } \\
\text { Management, Wealth } \\
\text { Management, Superannuation, } \\
\text { Banking }\end{array}$ & $25 \%$ \\
\hline A07 & $\begin{array}{l}\text { Small } \\
\text { Australia }\end{array}$ & Partner & $\begin{array}{l}\text { Financial Planning, Mortgage } \\
\text { Broking, Superannuation, } \\
\text { Business Strategy, General } \\
\text { Business Advice }\end{array}$ & $50 \%$ \\
\hline A08 & $\begin{array}{l}2^{\text {nd }} \text { Tier } \\
\text { UK }\end{array}$ & $\begin{array}{l}\text { Partner-- } \\
\text { SME Clients }\end{array}$ & $\begin{array}{l}\text { Business Purchase and Sale, } \\
\text { HR, Financial Management, } \\
\text { Company Secretarial }\end{array}$ & $\mathrm{n} / \mathrm{a}$ \\
\hline A09 & $\begin{array}{l}\text { Medium } \\
\text { UK }\end{array}$ & $\begin{array}{l}\text { Partner-- } \\
\text { SME Client } \\
\text { Services } \\
\end{array}$ & $\begin{array}{l}\text { Company Secretarial, HR, } \\
\text { Business Purchase and Sale }\end{array}$ & $50 \%$ \\
\hline A10 & $\begin{array}{l}\text { Medium } \\
\text { UK }\end{array}$ & Partner & $\begin{array}{l}\text { Financial planning, retirement } \\
\text { planning }\end{array}$ & $100 \%$ \\
\hline A11 & $\begin{array}{l}\text { Medium } \\
\text { UK }\end{array}$ & $\begin{array}{l}\text { Partner } \\
\text { Financial } \\
\text { Adviser (Part of } \\
\text { Accountancy } \\
\text { Firm) } \\
\end{array}$ & $\begin{array}{l}\text { Financial Planning, Retirement } \\
\text { Planning, Pensions, Protection }\end{array}$ & $100 \%$ \\
\hline A12 & $\begin{array}{l}2^{\text {nd }} \text { Tier } \\
\text { UK }\end{array}$ & Partner & $\begin{array}{l}\text { Succession planning, Tax audit } \\
\text { assistance, Business planning, } \\
\text { corporate finance, recruitment } \\
\text { advice }\end{array}$ & $20 \%$ \\
\hline
\end{tabular}




\section{Responses to Reviewer's Comments}

We take this opportunity to thank you for the opportunity to revise our manuscript and to express our appreciation for your effort and helpful comments. We have redrafted the paper to incorporate your suggestions and we believe the paper is much improved. Responses to each of the comments are explained below:

Editor's Comment

Response

The reviewer has recommended publication, subject to some minor revisions to your manuscript. Therefore, I invite you to respond to the reviewer's comments and revise your manuscript. I think you will find that these comments are relatively straight forward and easy to address. In regard to the last comment (re adding to agency theory), I will leave it with you whether to follow the reviewer's suggestion to elaborate this argument, or to simply remove this claim. I suggest that you make the revisions as quickly as you can, as there may be the opportunity to squeeze your paper into Issue 1 of QRAM for 2018. If not, then it will have to go into Issue 3 for 2018, since Issue 2 is reserved for a special issue.
We are pleased that the reviewer and the editor both consider the paper to be much improved. We also would like to acknowledge the editor's helpful comments and for facilitating a very constructive refereeing process.

As suggested by the reviewer, we have removed the claim from the paper that "our conceptual model augments agency theory - the dominant theoretical paradigm explaining demand for accounting and audit services (Lambert 2001)".

\section{Response}

1. At present, the introduction is rather long and needs to be sharpened, in my view. To this purpose, I would suggest trying to reduce its length and concentrate on the motivations for the study, the key issues and problems at stake, the research objectives and the main contributions. Some of the arguments made in the introduction can be moved to the literature review in the subsequent section, which at present remains predominantly descriptive and unproblematic. In fact, the section titled 'Unpacking relationship in business advisory services' would benefit from the elaboration of some of the points raised in the introduction. Also, I wonder whether it could benefit from the insights offered
We are pleased that the reviewer considers the paper to be much improved. We would like to acknowledge the reviewer's helpful comments and for the very constructive refereeing process.

We have reduced the introduction by four pages and have considerably sharpened the focus of the introduction, which is now threepages long. The introduction focuses on the motivations, the key issues and problems, the research objectives, and the main contributions of the study. As suggested, some of the 


\begin{tabular}{|c|c|c|}
\hline & $\begin{array}{l}\text { by more recent studies on the topic (the } \\
\text { literature reviewed here is rather } \\
\text { outdated). Finally, the key messages } \\
\text { learnt from the literature reviewed in this } \\
\text { section, and leading to the subsequent } \\
\text { sections, could be made more explicit. }\end{array}$ & $\begin{array}{l}\text { argumentation which had been in the } \\
\text { introduction has now been moved to } \\
\text { the section titled 'Unpacking } \\
\text { relationship in business advisory } \\
\text { services' as well as into the sections } \\
\text { titled 'Conceptualising Trust' and } \\
\text { 'Conceptual Framework Explaining } \\
\text { SME Demand for Business Advice'. } \\
\text { We undertook an extensive literature } \\
\text { search with the aim of identifying } \\
\text { more recent studies on the topics } \\
\text { discussed in the literature review. } \\
\text { Our search revealed that we are } \\
\text { unable to include any more recent } \\
\text { studies (citations) that are relevant to } \\
\text { our topic. }\end{array}$ \\
\hline & $\begin{array}{l}\text { To my understanding, the literature } \\
\text { review on business advisory services and } \\
\text { trust leads the authors to draft the } \\
\text { theoretical framing in figure } 1 \text {. However, I } \\
\text { would suggest the authors to provide } \\
\text { clearer links between the two. A possible } \\
\text { way for doing it could be to number each } \\
\text { element of the framework in figure } 1 \text {, or } \\
\text { label it with a letter, and then refer to it in } \\
\text { the literature review. Each element needs } \\
\text { to be clearly derived from the literature, } \\
\text { providing critical arguments about its } \\
\text { choice as part of the framework. }\end{array}$ & $\begin{array}{l}\text { The paper now explains more clearly } \\
\text { the links between the elements of } \\
\text { the conceptual framework in Figures } \\
1 \text { and } 2 \text { and the literature review. } \\
\text { Indeed, we have included an } \\
\text { additional figure (see Figure } 2 \text { ) in the } \\
\text { paper to more clearly explain the } \\
\text { conceptual framework. }\end{array}$ \\
\hline 3. & $\begin{array}{l}\text { Similar references to Figure } 1 \text { might be } \\
\text { provided in the empirical analysis. }\end{array}$ & $\begin{array}{l}\text { Where appropriate we have now } \\
\text { made reference to our conceptual } \\
\text { model (Figure } 2 \text { ) in the empirical } \\
\text { analysis. }\end{array}$ \\
\hline 4. & $\begin{array}{l}\text { In the introduction, the authors mention } \\
\text { that this research may offer important } \\
\text { insights to the accounting profession, as } \\
\text { well as accounting bodies. However this } \\
\text { point is not fully addressed in the } \\
\text { concluding section and may deserve to be } \\
\text { strengthened further as a contribution of } \\
\text { the paper. What can accounting bodies } \\
\text { learn from this research, and how could } \\
\text { they benefit from the proposed }\end{array}$ & $\begin{array}{l}\text { We have extended the discussion of } \\
\text { implications of research in the } \\
\text { conclusion. }\end{array}$ \\
\hline
\end{tabular}


Page 41 of 41

Qualitative Research in Accounting and Management

Responses to Reviewer's Comments

3

$$
\begin{aligned}
& 1 \\
& 2 \\
& 3 \\
& 4 \\
& 5 \\
& 6 \\
& 7 \\
& 8 \\
& 9 \\
& 10 \\
& 11 \\
& 12 \\
& 13 \\
& 14 \\
& 15 \\
& 16 \\
& 17 \\
& 18 \\
& 19 \\
& 20 \\
& 21 \\
& 22 \\
& 23 \\
& 24 \\
& 25 \\
& 26 \\
& 27 \\
& 28 \\
& 29 \\
& 30 \\
& 31 \\
& 32 \\
& 33 \\
& 34 \\
& 35 \\
& 36 \\
& 37 \\
& 38 \\
& 39 \\
& 40 \\
& 41 \\
& 42 \\
& 43 \\
& 44 \\
& 45 \\
& 46 \\
& 47 \\
& 48 \\
& 49 \\
& 50 \\
& 51 \\
& 52 \\
& 53 \\
& 54 \\
& 55 \\
& 56 \\
& 57 \\
& 50
\end{aligned}
$$

theoretical framework? The answer to these questions could be reinforced as part of the conclusion.

5. Finally, I am not convinced by the assertion that the paper's conceptual model augment agency theory. Agency theory is not fully reviewed in the paper and not clearly embedded in the theoretical framework. As such, this point remains unconvincing in my view. It requires to be explained and elaborated further if the authors wish to provide convincing arguments on this regard. I hope my suggestions will help in refining the paper further.
As suggested by the reviewer, we have removed the claim from the paper that "our conceptual model augments agency theory - the dominant theoretical paradigm explaining demand for accounting and audit services (Lambert 2001)". 